\title{
CYTOTOXIC ACTIVITY OF THE CLUSTER RHENIUM COMPOUND WITH $\beta$-ALANINE LIGANDS
}

\author{
K. V. POLOKHINA ${ }^{1}$, D. E. KYTOVA ${ }^{1}$, A. V. SHTEMENKO ${ }^{1}$, N. I. SHTEMENKO ${ }^{1,2 ⿴ 囗}$ \\ ${ }^{1}$ Ukrainian State University of Chemical Technology, Dnipro, Ukraine; \\ ${ }^{2}$ Dnipro University of Technology, Ukraine;

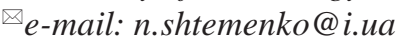

Received: 25 February 2019; Accepted: 29 November 2019

Earlier we have shown that cluster rhenium compounds not only inhibited tumor growth in vivo but also supported the antioxidant state of experimental animals. Further investigation of new dirhenium(III) and cluster rhenium compounds in human leukemic cells is of great importance. The aim of the recent work was to investigate the cytotoxic activity of the new cluster rhenium compound with $\beta$-alanine ligands $\left[\mathrm{Re}_{2} \mathrm{Cl}_{6}\left(\mathrm{C}_{3} \mathrm{H}_{7} \mathrm{NO}_{2}\right)_{2}\right] \cdot 1.5 \mathrm{H}_{2} \mathrm{O}(\mathrm{I})$ in the solutions and nanoliposomes alone and together with cisplatin in Jurkat cells. It was shown that I in solution had cytotoxicity close to cisplatin $\left(L C_{50}=2.06 \cdot 10^{-6} \mathrm{M}\right)$. The administration of the rhenium-platinum system with I showed increased cytotoxic activity, especially high when both components of the system were in the mixed liposomes together $\left(L C_{50}=4.93 \cdot 10^{-10} \mathrm{M}\right)$. The new dirhenium dicarboxylate complex with zwitterionic amino acid ligands possesses an appreciable cytotoxic and proapoptotic activity against leukemic cells, especially in combination with cisplatin, guiding the search for novel active rhenium compounds and development of improved regimens for combined chemotherapy based on combination of rhenium-platinum compounds.

Ke y wo rd s: cluster rhenium compound, rhenium-platinum system, cytotoxic activity, apoptosis.

$\mathrm{O}$ ur previous studies showed the anticancer activity of cluster rhenium compounds in the model of Guerin's carcinoma, especially significant being administered simultaneously with cisplatin (cisPt) in the molar ratio 4:1 and the effective antitumor rhenium-platinum system was developed [1-4]. It was shown that cluster rhenium compounds interacted with native supercoiled DNA; this mechanism of the interaction was redox-activated. Antioxidant and antiradical properties of cluster rhenium compounds were also demonstrated. In this and other papers, it was shown that cis-dicarboxylates of dirhenium(III) with alkyl ligands had a moderate anticancer activity (30-45\% inhibition of tumour growth) but following synthesis of substances with amino acids ligands instead of alkyl ligands resulted in more effective tumor inhibition (up to 65\%) [2]. Such phenomenon was explained by the presence of the positive charge on the amino groups in ligands - derivatives of amino acids, unlike the alkyl ones, which could contribute to the electrostatic interaction with negatively charged phosphate groups of DNA.

Recently, a cis-dicarboxylate compound with $\beta$-alanine ligands was synthesized [5], Fig. 1. We expected that rhenium compound with amino acid ligands such as I should have a more prominent effect as a cytostatic.

Further investigation of the influence of new dirhenium(III) compounds and rhenium-platinum on the human cancer cells is of great importance.

It is known that liposomal drugs are more effective in cancer cells growth inhibition than aqueous solutions [6, 7].

Nanoliposomes containing both rhenium compound and cisplatin (the so-called mixed liposomes or nanobins) were recently synthesized by us [8] and were shown to have higher anticancer effect in

(C) 2020 Polokhina K. V. et al. This is an open-access article distributed under the terms of the Creative Commons Attribution License, which permits unrestricted use, distribution, and reproduction in any medium, provided the original author and source are credited. 


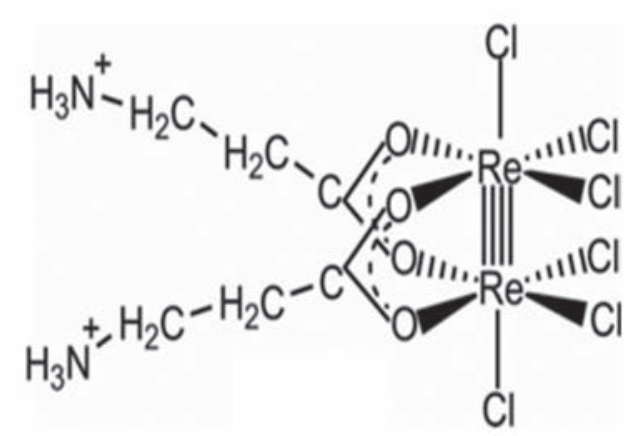

Fig. 1. Structure of $\left[\mathrm{Re}_{2} \mathrm{Cl}_{6}\left(\mathrm{C}_{3} \mathrm{H}_{7} \mathrm{NO}_{2}\right)_{2}\right]$ Hexachlorodi- $\mu$-3-aminopropionatodirhenium(III) (I)

comparison to separately administered cytostatics in vivo. The interaction of such nanoliposomes with cancer cells has not yet been studied.

T-cells of acute lymphoblastic leukemia (Jurkat cells) are widely used in cell biology to investigate receptors of T-cell signaling [9].

Given the above, the aim of the paper was to study in vitro cytotoxic properties of the cluster rhenium compound of the cis-dicarboxylate structural type with $\beta$-alanine ligands I and the rhenium-platinum system on its base introduced to medium in solution, in liposomal forms separately and in the form of mixed liposomes.

\section{Materials and Methods}

Cisplatin and hexachlorodi- $\mu$-3-aminopropionatodirhenium(III) (I) were synthesized at Ukrainian State University of Chemical Technology at the Department of Inorganic Chemistry [5, 10]. Jurkat cells were obtained from the Institute of Cell Biology National Academy of Sciences of Ukraine (Lviv).

The following treatment variants were assessed: solution of cisplatin CisPt; solution of I (I); $\mathbf{I}$ in liposomal form [I] ; The final concentrations of the administered rhenium substances were $10^{-5}, 10^{-6}$, $10^{-7}, 10^{-8}$ and $10^{-9} \mathrm{M}$. The rhenium-platinum system was administered in two variants: I in liposomes and cisplatin solution in molar ratio 4:1 [I] + CisPt; I and cisplatin in a molar ratio $4: 1$ in the form of mixed liposomes $-[\mathbf{I}+\mathrm{CisPt}]$ so that the concentration of cisplatin was $10^{-5}, 10^{-6}, 10^{-7}, 10^{-8}$ and $10^{-9} \mathrm{M}$.

Jurkat cells were cultured in $20 \mathrm{~cm}^{2}$ Carrel glass culture flasks in RPMI 1640 medium (Sigma, USA) supplemented with $10 \%$ bovine serum (Sigma, USA). The cells were passaged every two days at the concentration of $5 \times 10^{5}$ cells $/ \mathrm{ml}$ of culture me- dium. The cells were plated in 24-well plastic plates (Sarsted, USA) at the concentration of $5 \times 10^{5}$ cells/ $\mathrm{ml}$. The studied compounds were added at various concentrations noted above. After $72 \mathrm{~h}$ of incubation, the alive and dead apoptotic cells were counted according to $[11,12]$. The viability of cells was assessed by dye exclusion test with $1 \%$ trypan blue [11]. LC $_{50}$ index was used, calculated as a concentration of drug, which kills $50 \%$ cells in comparison with a control culture by Reed-Muench method [13].

To evaluate the apoptotic cells, $1 \mu 1$ of $1 \%$ orange acridine solution (excitation region 360-460 nm and emissions 480-700 nm, AO, Sigma, USA) was added to $100 \mu \mathrm{l}$ of cell suspension. After 20-30 min of incubation, cells were counted in Goryaev chamber on luminescent microscope Mikmed-2 ver.12 (LOMO St. Petersburg, Russia) at 400x magnification in the excitation region of $450-480 \mathrm{~nm}$ and emission of 500-530 nm. Under these conditions, the live, apoptotic and dead cells were differentiated by the distribution of colors in the cytoplasm and nuclei morphology.

Statistical analysis of the obtained data was carried out using the Student's $t$-test $(P \leq 0.05)$. The data were expressed as $M \pm m$.

\section{Results and discussion}

The dependence of viability of the cells from the concentration of $\mathbf{I}$ in soluble and liposomal form $[\mathbf{I}]$ is shown in Fig. 2.

As it was expected, the cytotoxic activity of the rhenium-platinum system was much higher than that of $\mathbf{I}$ in free and liposomal form (Fig. 3).

$\mathrm{LC}_{50}$ values for the studied substances are presented in the Table.

It is obvious that $\mathbf{I}$ had cytotoxic activity close to cisplatin. The $\mathrm{LC}_{50}$ calculations showed the rhenium compound cytotoxicity against Jurkat cells and proved the significant advantage of cytotoxic activity of the system in liposomal forms as compared to

$L C_{50}$ values for the studied substances

\begin{tabular}{c|c}
\hline Administration & $\mathrm{LC}_{50}, \mathrm{M}$ \\
\hline CisPt & $1.92 \cdot 10^{-6}$ \\
$\mathbf{I}$ & $2.06 \cdot 10^{-6}$ \\
{$[\mathbf{I}]$} & $1.98 \cdot 10^{-6}$ \\
{$[\mathbf{I}]+\mathrm{CisPt}$} & $1.29 \cdot 10^{-8}$ \\
{$[\mathbf{I}+\mathrm{CisPt}]$} & $4.93 \cdot 10^{-10}$ \\
\hline
\end{tabular}




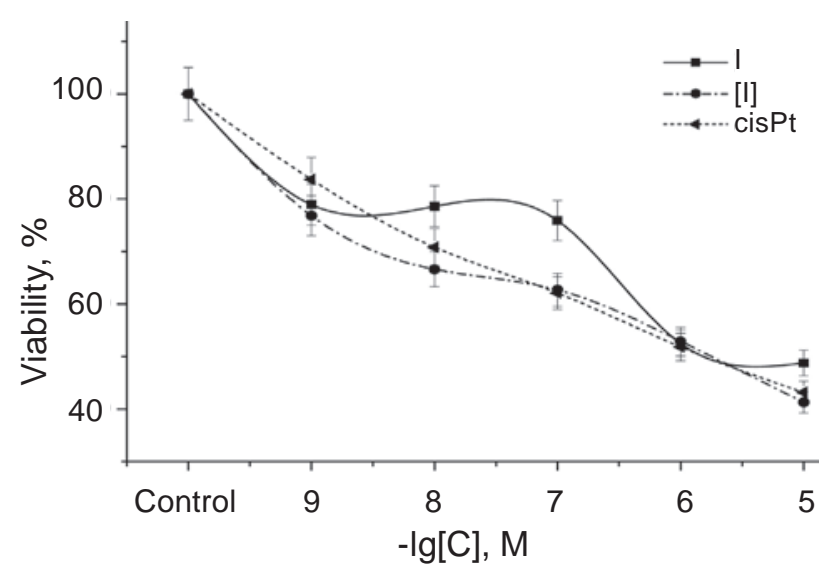

Fig. 2. Cytotoxicity of CisPt and $\mathbf{I}$ in free and $\mathbf{I}$ in liposomal form [I]

cisplatin. The form of nanobins (both components of the system in the liposome) was 26 times more effective than the system, where only component I was encapsulated in the liposome.

The $\mathrm{LC}_{50}$ value for $\mathbf{I}$ in various forms of administration, including co-administration with cisplatin, was 5-10 times less than for the rhenium compound with alkyl ligands [1-4], that confirms the rationality of the selected synthetic strategy for the creation of effective anticancer substances based on the dirhenium compounds, containing the positively charged ligands.

Comparing the $\mathrm{LC}_{50}$ values for known antitumor drugs and rhenium-platinum system in the form of nanobins $[\mathbf{I}+\mathrm{CisPt}]$, obtained on the same cell line, it should be noted that the system was much more effective than some antitumor drugs such as taxol (Paclitaxel [14], doxorubicin, newly synthe-

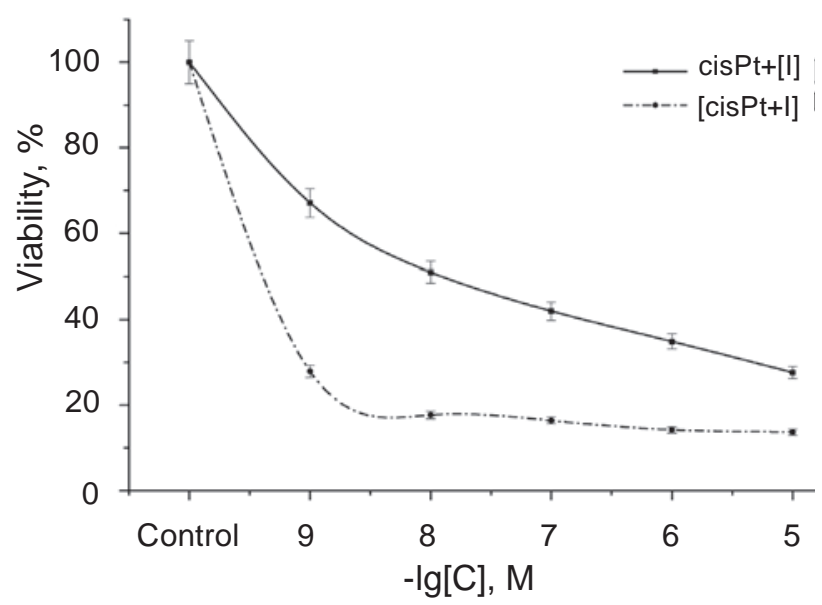

Fig. 3. The cytotoxic activity of the rhenium-platinum antitumor system sized heterocyclic 4-thiazolines, landomycin A, adriamycin[12] and palladium complexes with organic ligands [15]. But it is necessary to underline, that these preparations were not administered in liposomal forms, as I was in our experiments.

We explain higher efficacy of the liposomal forms of the studied drugs by several factors: first, the better delivery system (nonspecific transport through the lipid matrix of membranes). It was shown that the liposomal form of cisplatin caused not only higher inhibition of lung carcinoma growth, but also reduced its resistance to cisplatin as compared to the free form [6, 7]; second, the prevention of negative pre-modification of cytostatics. The process of cisplatin penetration into the Jurkat cell was studied and it was shown that its active absorption occurred only in the first hour after cisplatin administration and later the formation of carbonate cisplatin derivative, which was unable to penetrate the cancer cell and to bind to DNA, took place extracellularly, in culture medium $[16,18]$. The authors considered that this phenomenon was some kind of unknown mechanism of cancer cell protection from the toxic form of cisplatin and may be the basis for the widely known phenomenon of resistance. As it was mentioned above, rhenium compounds were characterized by hydrolysis in aqueous solutions, the speed of which depended on the $\mathrm{pH}$ and from the structure of the complex [1]. Encapsulation to lipid shell protected them from hydrolysis; third, it was shown that cluster rhenium compounds interacted with phosphate residues of phospholipids (also with cisplatin) and formed equilibrium inside the liposome, contributing to the increasing of the chemical potential of the encapsulated substances [8]. Thus, the lipid encapsulation of rhenium compounds and cisplatin increased the concentration of these cytostatics in the cancer cell through a simplified transport mechanism and the deprivation of the possibility to deactivate these compounds in the culture environment that leads to increasing of the compounds' reactivity.

Both necrotic and apoptotic pathways of cells death are common for Jurkat cells [11, 12, 17]. Proapoptotic concentrations of cisplatin (up to $30 \mu \mathrm{M}$ ) induced apoptosis. Under pro-necrotic concentrations (above $300 \mu \mathrm{M}$ ), the inhibition of mitochondrial functions of the Jurkat cells took place [18]. Direct inhibition of the respiratory chain rapidly depletes cellular ATP by triggering a non-apoptotic (necrotic) pathway of cell death. In our experiments, we also observed the existence of two cell death pathways. 
Indeed, under high concentrations $\left(10^{-5}-10^{-6} \mathrm{M}\right)$ of cisplatin, the number of cells dying under the apoptotic mechanism was only $6.12-38.24 \%$ of the total number of dead cells (Fig. 4).

At low concentrations of cisplatin, the apoptotic pathway of cell death predominated. However, even high concentrations of $\mathbf{I}$, unlike cisplatin, caused predominantly apoptotic pathway of cell death, while this effect was practically independent of the I concentration. The liposomal form of I was more active in the concentrations of $10^{-6}$ and $10^{-7} \mathrm{M}$. Palladium-based organometallic compounds also had predominant, concentration - independent apoptotic mechanism of action on Jurkat cells [15]. This mechanism of induction of apoptosis by metalcontaining substances has not been studied and to our mind is of great interest.

Introduction of $\mathbf{I}$ and cisplatin also led to the formation of a large number of apoptotic cells (Fig. 5).

According to these data, it is possible to suppose that the cluster rhenium compound at high concentration "prevented" the pronecrotic cisplatin activity. It should be noticed that the system in the form of nanobins was more effective in proapoptotic activity almost at the whole range of concentrations except the concentration of $10^{-9} \mathrm{M}$ as compared to the system with free cisplatin.

The type of cell death is mostly ignored when evaluating the effectiveness of anticancer activity of a substance, as $\mathrm{LC}_{50}$ value is calculated by the number of viable cells remaining after incubation. However, it is very important for therapeutic measures and side effects, since necrosis activates inflammation and an immune response that is not inherent to apoptosis [17]. Consequently, the presence of proapoptotic cytostatics is a very important area in the anticancer studies.

It should be noted that cisplatin is a prooxidant, and cluster rhenium compounds are powerful antioxidants [1-4]. They contain quadruple bond, formed by one $\sigma$-bond, two $\pi$-bonds and $\delta$-bond; the last may be formed only from d-electrons of heavy metals. This is the base of mighty antiradical, antioxidant properties of cluster rhenium compounds, which are $\delta$-antioxidants and far exceed such properties of $\pi$-conjugated conventional antioxidants. Chemotherapy aimed to change the level of reactive oxygen species (ROS) in cancer cells (modulation of redox state) is considered to be a promising strategy in cancer care. The most common hypothesis that proves the effectiveness of such a strategy is following: a cancer cell, unlike a normal one, has a high level of ROS; high level of ROS suppresses the antioxidant defence system, that is unable to respond to the sudden increase in the concentration of ROS, induced by administration of ROS-induced agents (drugs); as a result of such a radical burst the cellular components are destructing and the cancer cell dies. This was partially confirmed by studies of ROS concen-

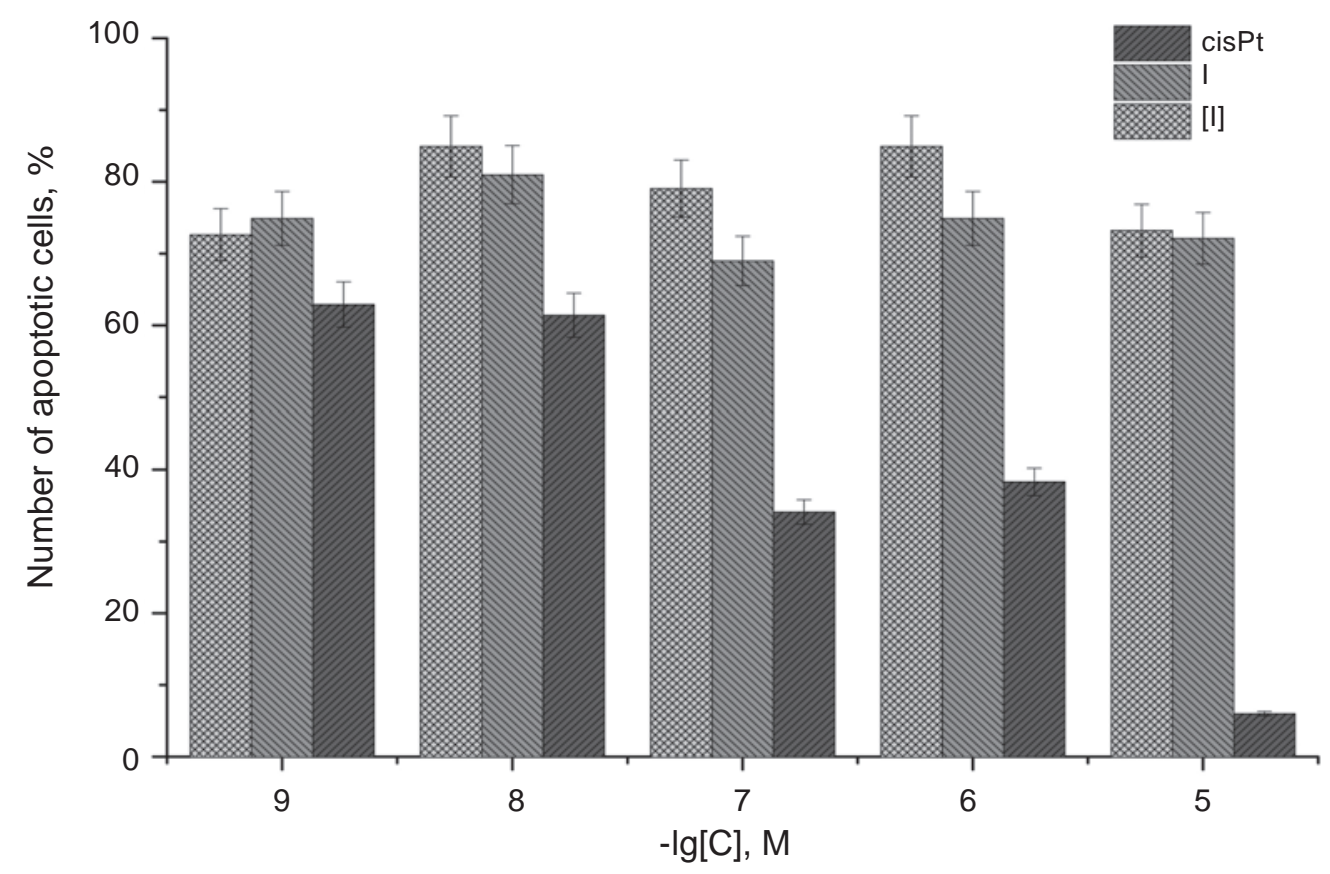

Fig. 4. Percentage of apoptotic cells in the total number of dead cells at the administration of cisplatin and $\mathbf{I}$ 


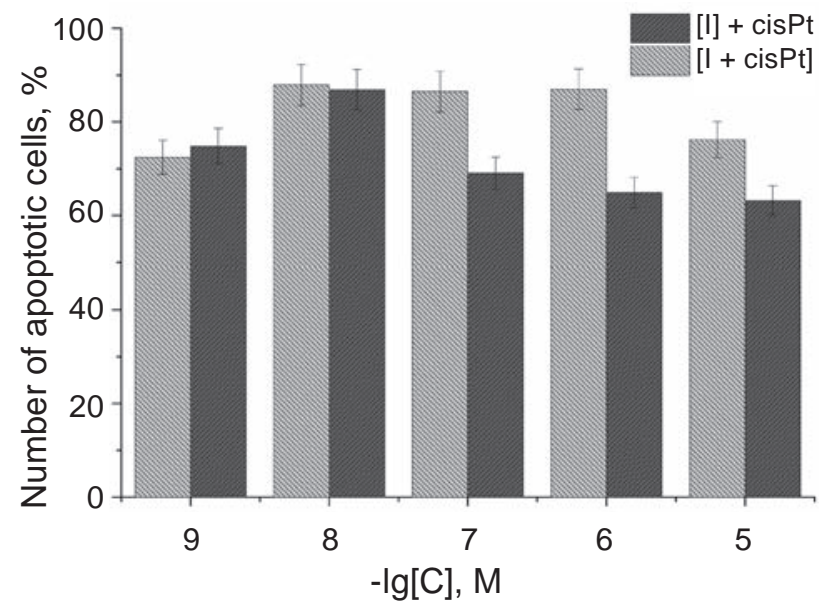

Fig. 5. Percentage of apoptotic cells in the total number of dead cells at the administration of the rhenium-platinum system

trations in Jurkat cells under apoptosis-induced antibiotic landomycin $\left(\mathrm{LC}_{50}=1.5 \mu \mathrm{M}\right)[11,12]$, normal the administration of which at concentration $1 \mu \mathrm{M}$ caused the 5.6-fold increase of ROS, followed by apoptotic death of cancer cells. The administration of antioxidant enzymes together with landomycin reduced the level of ROS and increased the quantity of survived cells. However, it was noted that an increased level of ROS is not a direct triggering factor of apoptosis mediated by mitochondria.

Also, antioxidants were shown to exhibit cytotoxic effects. For example, umbeliprenin (terpenoid coumarin, $\pi$-conjugated antioxidant) caused apoptotic death of Jurkat cells $\left(\mathrm{LC}_{50}=25 \mu \mathrm{M}\right)$, even in the presence of interleukin [4], which initiated resistance to apoptotic death of leukaemic cells [21].

An attempt was made to modulate the cytotoxic effect of cisplatin and doxorubicin with the help of some antioxidants (sodium selenite, selenomethionine, D-pantethine) in several human cancer cells, also in Jurkat cells $[11,12]$. Unlike doxorubicin, the toxicity of which towards Jurkat cells was reduced, there were no statistically significant changes in the effect of antioxidants on the viability of cells after cisplatin action.
On the other hand, the anticancer effect of such antioxidants as curcuminoids is well-known [22, 23]. It was explained by inhibition of NF- $\kappa \mathrm{B}$ pathway by reducing ROS concentrations, that were shown to be signaling molecules for NF- $\mathrm{KB}$ pathway and directly inhibited competent immune cells (ICC) - kinase activity by modifying cysteine residues critical for functioning of cancer cells [24, 25].

Unfortunately, signalling pathways of cancer cells that are influenced by cluster rhenium compounds have not been studied. It is known that these compounds are traps for radicals due to quadruple bond, but as mentioned above, they also interact with DNA and histidine residues of proteins depending on the structure and orientation of the ligands around the cluster fragment, i.e., additionally have diverse coordination functions [4]. Therefore, to our opinion, the anticancer effect of these compounds depends not only on their antioxidant properties, but also on their possibility to affect other regulatory processes of cancer cell.

The results obtained showed the availability of the use of dirhenium compounds as anticancer substances and emphasized the need for further study of mechanisms of anticancer activity of cluster rhenium compounds with organic ligands of various nature.

Thus, the new dirhenium dicarboxylate complex with zwitterionic amino acid ligands possesses an appreciable cytotoxic activity against leukemic cells. The compound also reveals mighty proapoptotic activity. This should find further applications for the development of new antitumor agents and confirms importance of the development of protocols for combined Re-cisPt chemotherapeutic procedures.

Conflict of interest. Authors have completed the Unified Conflicts of Interest form at http://ukrbiochemjournal.org/wp-content/uploads/2018/12/ coi_disclosure.pdf and declare no conflict of interest.

Acknowledgment. We wish to thank Professor Stoika R. S. from the Institute of Cell Biology of National Academy of Sciences of Ukraine (Lviv) for his kindly help in the experimental work. 


\section{ЦИТОТОКСИЧНА АКТИВНІСТЬ КЛАСТЕРНОЇ СПОЛУКИ РЕНІЮ 3 ק-АЛАНІНОВИМИ ЛІГАНДАМИ}

\author{
К. В. Полохіна ${ }^{1}$, Д. С. Китова ${ }^{1}$, \\ О. В. Штеменко ${ }^{1}$, Н. I. Штеменко ${ }^{1,2 \bowtie}$

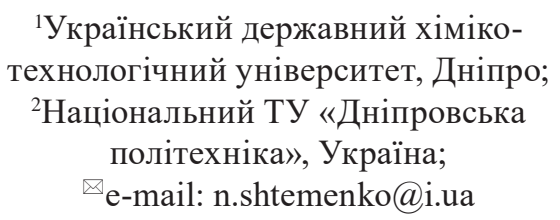

Раніше нами було показано, що кластерні сполуки ренію не лише пригнічують пухлинний ріст in vivo, але й підтримують антиоксидантний статус експериментальних тварин. Подальші дослідження впливу нових синтезованих сполук диренію(III) та кластерних сполук ренію на лейкемічні клітини людини $\epsilon$ важливими. Метою цієї роботи було дослідити цитотоксичну активність нової кластерної сполуки ренію з $\beta$-аланіновими лігандами $\left[\mathrm{Re}_{2} \mathrm{Cl}_{6}\left(\mathrm{C}_{3} \mathrm{H}_{7} \mathrm{NO}_{2}\right)_{2}\right] \cdot 1.5 \mathrm{H}_{2} \mathrm{O}$ (I) у розчинах $\mathrm{i}$ наноліпосомах окремо та разом 3 цисплатином на клітинах Jurkat. Показано, що цитотоксичність I у розчині близька за значенням $\mathrm{LC}_{50}$ до цисплатину $\left(\mathrm{LC}_{50}=2,06 \cdot 10^{-6} \mathrm{M}\right)$. Застосування системи реній-платина у комбінації з I показало збільшення цитотоксичності, особливо коли обидва компоненти системи знаходилися у формі змішаних ліпосом $\left(\mathrm{LC}_{50}=4,93 \cdot 10^{-10} \mathrm{M}\right)$. Отже, нова сполука ренію зі структурою дикарбоксилату з цвітер-іонними лігандами має значну цитотоксичну і проапоптотичну дію в культуpi лейкемічних клітин, особливо в комбінації 3 цисплатином, що підкреслює важливість подальшого пошуку нових активних сполук ренію та розробки нових протоколів для комбінаційної хіміотерапії на основі систем реній-платина.

К л ю ч о в і с ло в а: кластерна сполука ренію, система реній-платина, цитотоксична активність, апоптоз.

\section{References}

1. Shtemenko NI, Zabitskaya ED, Berzenina OV, Yegorova DE, Shtemenko AV. Liposomal forms of rhenium cluster compounds: enhancement of biological activity. Chem Biodivers. 2008; 5(8): 1660-1667.

2. Shtemenko AV, Collery P, Shtemenko NI, Domasevitch KV, Zabitskaya ED,
Golichenko AA. Synthesis, characterization, in vivo antitumor properties of the cluster rhenium compound with GABA ligands and its synergism with cisplatin. Dalton Trans. 2009; (26): 5132-5136.

3. Shtemenko NI, Chifotides HT, Domasevich KV, Golichenko AA, Babiy SA, Li Z, Paramonova KV, Shtemenko AV, Dunbar KR. Synthesis, X-ray structure, interactions with DNA, remarkable in vivo tumor growth suppression and nephroprotective activity of cistetrachloro-dipivalato dirhenium(III). J Inorg Biochem. 2013; 129: 127-134.

4. Shtemenko AV, Shtemenko NI. Rheniumplatinum antitumor systems. $U \mathrm{kr}$ Biochem $\mathrm{J}$. 2017; 89(2): 5-30.

5. Golichenko AA, Domasevitch KV, Kytova DE, Shtemenko AV. Crystal structure of cis-bis- $(\mu-\beta-$ alanine- $\kappa(2)$ O:O')bis[tri-chlorido-rhenium(III)] (Re-Re) sesquihydrate. Acta Crystallogr E Crystallogr Commun. 2015; 71(Pt 1): 45-47.

6. Slingerland M, Guchelaar HJ, Gelderblom H. Liposomal drug formulations in cancer therapy: 15 years along the road. Drug Discov Today. 2012; 17(3-4): 160-166.

7. Hyodo K, Yamamoto E, Suzuki T, Kikuchi H, Asano M, Ishihara H. Development of liposomal anticancer drugs. Biol Pharm Bull. 2013; 36(5): 703-707.

8. Li Z, Shtemenko NI, Yegorova DY, Babiy SO, Brown AJ, Yang T, Shtemenko AV, Dunbar KR. Liposomes loaded with a dirhenium compound and cisplatin: preparation, properties and improved in vivo anticancer activity. $J$ Liposome Res. 2015; 25(1): 78-87.

9. Abraham RT, Weiss A. Jurkat $\mathrm{T}$ cells and development of the T-cell receptor signalling paradigm. Nat Rev Immunol. 2004; 4(4): 301308.

10. Klucnikov NG. Handbook on Inorganic Synthesis. M.: Khimiia, 1965. P. 184-186. (In Russian).

11. Panchuk R, Skorokhyd N, Chumak V, Lehka L, Omelyanchik S, Gurinovich V, Moiseenok A, Heffeter P, Berger Wr, Stoika R. Specific antioxidant compounds differentially modulate cytotoxic activity of doxorubicin and cisplatin: in vitro and in vivo study. Croat Med J. 2014; 55(3): 206-217.

12. Lehka LV, Panchuk RR, Berger W, Rohr Ju, Stoika RS. The role of reactive oxygen species in 
tumor cells apoptosis induced by landomycin A. Ukr Biochem J. 2015; 87(5): 72-82.

13. Ramakrishnan MA. Determination of $50 \%$ endpoint titer using a simple formula. World $J$ Virol. 2016; 5(2): 85-86.

14. Liebmann JE, Cook JA, Lipschultz C, Teague D, Fisher J, Mitchell JB. Cytotoxic studies of paclitaxel (Taxol) in human tumour cell lines. Br J Cancer. 1993; 68(6): 1104-1109.

15. Antunovic M, Kriznik B, Ulukaya E, Yilmaz VT, Mihalic KC, Madunic J, Marijanovic I. Cytotoxic activity of novel palladium-based compounds on leukemia cell lines. Anticancer Drugs. 2015; 26(2): 180-186.

16. Centerwall CR, Tacka KA, Kerwood DJ, Goodisman J, Toms BB, Dubowy RL,Dabrowiak JC. Modification and uptake of a cisplatin carbonato complex by Jurkat cells. Mol Pharmacol. 2006;70(1):348-355.

17. Sancho-Martínez SM, Piedrafita FJ, CannataAndía JB, López-Novoa JM, LópezHernández FJ. Necrotic concentrations of cisplatin activate the apoptotic machinery but inhibit effector caspases and interfere with the execution of apoptosis. Toxicol Sci. 2011; 122(1): 73-85.

18. Tacka KA, Dabrowiak JC, Goodisman J, Penefsky HS, Souid AK. Effects of cisplatin on mitochondrial function in Jurkat cells. Chem Res Toxicol. 2004; 17(8): 1102-1111.

19. Jung Y, Lippard SJ. Direct cellular responses to platinum-induced DNA damage. Chem Rev. 2007; 107(5): 1387-1407.
20. Shtemenko AV, Chifotides HT, Yegorova DE, Shtemenko NI, Dunbar KR. Synthesis and X-ray crystal structure of the dirhenium complex $\mathrm{Re}_{2}\left(\mathrm{i}-\mathrm{C}_{3} \mathrm{H}_{7} \mathrm{COO}\right)_{4} \mathrm{Cl}_{2}$ and its interactions with the DNA purine nucleobases. J Inorg Biochem. 2015; 153: 114-120.

21. Ziai SA, Gholami O, Iranshahi M, Zamani AH, Jeddi-Tehrani M. Umbelliprenin Induces Apoptosis in CLL Cell Lines. Iran J Pharm Res. 2012; 11(2): 653-659.

22. Olivera A, Moore TW, Hu F, Brown AP, Sun A, Liotta DC, Snyder JP, Yoon Y, Shim H, Marcus AI, Miller AH, Pace TW. Inhibition of the NF- $\kappa B$ signaling pathway by the curcumin analog, 3,5-Bis(2-pyridinylmethylidene)-4piperidone (EF31): anti-inflammatory and anticancer properties. Int Immunopharmacol. 2012; 12(2): 368-377.

23. Wilken R, Veena MS, Wang MB, Srivatsan ES. Curcumin: A review of anti-cancer properties and therapeutic activity in head and neck squamous cell carcinoma. Mol Cancer. 2011; 10: 12.

24. Gupta SC, Sundaram C, Reuter S, Aggarwal BB. Inhibiting NF- $\mathrm{KB}$ activation by small molecules as a therapeutic strategy. Biochim Biophys Acta. 2010; 1799(10-12): 775-787.

25. Gilmore TD, Herscovitch M. Inhibitors of NFkappaB signaling: 785 and counting. Oncogene. 2006; 25(51): 6887-6899. 